\title{
Testing the Proposed Municipality Resilience Index to Climate Change Shocks and Stresses in Mbale Municipality in Eastern Uganda
}

\author{
George Oriangi1,2,3,4* ${ }^{\mathbb{B}}$, Yazidhi Bamutaze1, Paul Isolo Mukwaya1, Paul Musali1, \\ Giuliano Di Baldassarre ${ }^{2}$, Petter Pilesjö3,5 \\ ${ }^{1}$ Department of Geography, Geo-Informatics and Climatic Sciences, Makerere University, Kampala, Uganda \\ ${ }^{2}$ Department of Earth Sciences, Centre of Natural Hazards and Disaster Science, Uppsala University, Uppsala, Sweden \\ ${ }^{3}$ Department of Physical Geography and Ecosystem Science, Lund University, Lund, Sweden \\ ${ }^{4}$ Department of Geography, Gulu University, Gulu, Uganda \\ ${ }^{5}$ Center for Middle Eastern Studies, Lund University, Lund, Sweden \\ Email: *georgeoriangi@gmail.com
}

How to cite this paper: Oriangi, G., Bamutaze, Y., Mukwaya, P.I., Musali, P., Di Baldassarre, G. and Pilesjö, P. (2019) Testing the Proposed Municipality Resilience Index to Climate Change Shocks and Stresses in Mbale Municipality in Eastern Uganda. American Journal of Climate Change, 8, 520-543.

https://doi.org/10.4236/ajcc.2019.84028

Received: September 29, 2019

Accepted: December 1, 2019

Published: December 4, 2019

Copyright $\odot 2019$ by author(s) and Scientific Research Publishing Inc. This work is licensed under the Creative Commons Attribution International License (CC BY 4.0).

http://creativecommons.org/licenses/by/4.0/

\begin{abstract}
Since climate change shocks and stresses cannot be fully prevented, building resilient urban areas is gaining more attention in the global community. By building resilience, the negative impacts of climate change shocks and stresses can be alleviated. Several indices have been developed to measure urban resilience. Yet, most of these indices focus more on objective methods which require robust bio-physical and socio-economic data sets which are generally lacking in many developing countries. To reduce this challenge, the use of subjective methods has recently been suggested. This study proposed and tested a Municipality Resilience Index (MRI) which employed a subjective method to assess the resilience of Mbale municipality in Eastern Uganda against climate change shocks and stresses. The proposed MRI includes 46 variables describing the physical, social, economic and institutional dimensions. The MRI can be applied in any municipality in developing countries facing climate related shocks and stresses and with limited survey data. The application of this index to Mbale municipality shows that the municipality has a low resilience index of 0.2. Similarly, most variables in the four dimensions of resilience reflected very low resilience scores with other divisions being more resilient than the others. Furthermore, the social dimension has the lowest score as compared to the physical, economic and institutional dimensions. The findings indicate a spatial variability in the contribution of the resilience dimensions within this small geographic confine. Moreover, the findings show the strengths and weaknesses in the different dimensions of the proposed MRI. This can act as a guide for policy and practitioners on which sectors to target in order to enhance the resilience of Mbale municipality.
\end{abstract}




\section{Keywords}

Urban, Resilience, Index, Climate Change, Shocks and Stresses

\section{Background}

The resilience of urban areas can counteract the increasing risks posed by climate change shocks and stresses [1]. Climate change shocks and stresses such as heavy precipitation events, flash floods, floods, heat waves and prolonged droughts are hitting hard on the urban areas of Sub Saharan Africa (SSA) [2] [3]. This is because urban areas of SSA tend to have low level of resilience at the same time concentrating population and socio-economic infrastructure that have often led to the destruction of the surrounding ecosystem [2] [3] [4]. This will even exacerbate the effects of climate change shocks and stresses on urban areas. Thus, urban areas need to assess their strengths and weaknesses in resilience building so as to prepare for the uncertain future. Although there has been a rapidly expanding body of knowledge on urban resilience among the scientific community [5] [6] [7], limited empirical findings exist on the resilience of urban areas to climate change related shocks and stresses in SSA [8] and yet such findings at a local scale are imperative in informing policies and practitioners that can help to enhance resilience.

Because of the complex nature of resilience as a concept, defining and developing a more applicable and context specific index for measuring urban resilience to climate related shocks and stresses is still an ongoing task [9]. Thus, numerous indices have been developed to measure urban resilience to climate related shocks and stresses, these include but not limited to: the Climate Disaster Resilience Index (CDRI) [10], The Integrated Resilience Index (IRI) [11], The Socio-ecological Index (SI) [12] and the Urban Resilience Index (URI) [13]. Despite this progress, most indices focus on assessing the resilience of mega cities and metropolitan areas in developed countries [14] [15] [16] [17]. Limited attention is thus given to municipalities and townships, yet these will play an important role in the strong urban growth trajectory projected over the next decades [18]. Furthermore, most indices employ objective methods that require robust socioeconomic and biophysical data sets which are generally lacking in many developing countries [9] [11] [19]. Additionally, some indices focus on specific sectors such as energy [20], drainage [21], cultural heritage [19] and remain silent about the principles of resilience that the variables address. Moreover, other indices investigate in detail a single dimension of resilience [3] [9]. However, urban areas are complex systems constituted of multiple dimensions. Thus, there is a need for a multidimensional, subjective approach which focuses on municipalities and townships of developing countries at the same time considering the qualities of resilience that variables measure.

Firstly, this study proposes a Municipality Resilience Index (MRI) for measuring resilience to climate change shocks and stresses and secondly, it tests the 
proposed index to measure the resilience of Mbale municipality against climate change shocks and stresses. The proposed index considers the physical, social, economic and institutional dimensions, it is subjective in nature at the same time observing the qualities of resilience to be measured.

In this study, climate change shocks refer to sudden and rapid disturbances caused by extreme weather conditions [11] while, climate change stresses refer to slow processes whose cumulative effects are felt after a long time [10]. Furthermore, the study uses the term subjective methods of resilience to mean those methods that obtain primary data using people's cognitive and self-evaluation of factors that could be influence to their resilience [22]. While objective methods of resilience mean those methods that employ robust secondary survey data for their analysis of resilience [23]. The study is divided into four sections, this current section presents the background of the study and a synthesis of literature on urban resilience indices, followed by the methods and approach, the results and discussion and the conclusion.

In ecology relating to ecosystem disturbances, resilience was defined as the capacity of a system to adapt to and either maintain its pre-disaster condition or the ability of a system to adapt, innovate and transform to a different state as a consequence of shocks or stresses [24]. Later, Holling [25] in the field of engineering, defined resilience as the capacity of material objects and physical structures to withstand disturbances without undergoing structural change. In this conceptualisation, resilience was taken to mean maintenance of pre-disaster status. In the fields of disaster risk reduction and climate change resilience studies, resilience is generally defined as the ability of a society or community to anticipate, respond to and recover from shocks and stresses, innovate and change its functioning [1] [11] [26]. In this conceptualisation, resilience is generally taken to mean a process of "bouncing forward". Just like there are many definitions of resilience, several indices have been developed to measure urban resilience to climate change shocks and stresses [6] [11] [20]. Thus, the conceptualization of resilience is contested depending on either the field of study or the index for measurement. As such, how to define resilience is still an ongoing debate [9]. Generally, resilience can be viewed in two perspectives i.e., static or maintenance of pre-disaster state and dynamic or a process of bouncing forward [11]. This study will adopt the dynamic view of resilience.

\subsection{Urban Resilience}

Urban resilience has been defined by a plethora of scholars, several times and in many different ways. Abdrabo and Hassaan defined urban resilience as "the ability of an urban system in all its dynamism to support, in the face of a hazard or pressure, the provision and accessibility to services and functions essential for the wellbeing of all residents, especially those lacking the means to buffer stresses" [11]. Batica and Gourbesville defined urban resilience as the ability of a system to function during and after a shock [1]. While, the United Nations University and Centre for Policy Research [27] defined urban resilience as "the abil- 
ity to activate protective qualities and processes at individual, community, institutional and systems level to engage with hazards and stresses and cooperate with each other in order to maintain or recover functionality and prosper while adapting to a new equilibrium and minimizing the accumulation of pre-existing or additional risks and vulnerabilities". Furthermore, The Rockefellers Foundation/Arup [28] defined urban resilience as the ability of an urban area to continue functioning such that its inhabitants more so the poor and vulnerable can be able to survive and thrive in the midst of shocks and stresses. This study will define urban resilience as the capacity of an urban system and all its constituent socio-ecological networks to absorb climate change shocks and stresses through preparedness and the capacity to recover and innovate when faced with climate change shocks and stresses [1] [10] [12].

\subsection{Indices Assessment Review}

Studies have developed several assessment indices that try to refine urban resilience into generally related dimensions such as the physical, natural, social, economic and institutional [1] [11] [29]. This study conducted a review of 17 indices that have been developed and used to measure urban resilience to climate change shocks and stresses (Table 1). These were grouped into indices that measure urban resilience to multiple climate change shocks and stresses, flood resilience indices and heat or drought resilience indices. The indices were reviewed to synthesize the dimensions used, the qualities observed by variables to monitor resilience, the scale of the urban area and the methods of data collection used.

Table 1. Indices for measuring urban resilience to climate change shocks and stresses. (a) Indices developed to measure city resilience to multiple climate change shocks and stresses; (b) Indices developed to measure resilience to floods; (c) Indices developed to measure resilience to droughts/heat.

(a)

\begin{tabular}{|c|c|c|c|}
\hline Author & Index & Dimensions & Details \\
\hline [19] & $\begin{array}{l}\text { Cultural Heritage } \\
\text { Risk Index (CHRI). }\end{array}$ & $\begin{array}{l}\text { Hazards, exposure } \\
\text { and vulnerability. }\end{array}$ & $\begin{array}{l}\text { Developed to assess resilience of cultural heritage in } \\
\text { Newcastle while employing objective methods. The index } \\
\text { showed that cultural assets were exposed to moderate risks } \\
\text { and a need for interventions to enhance resilience. }\end{array}$ \\
\hline [23] & $\begin{array}{l}\text { City Resilience } \\
\text { Index (CRI). }\end{array}$ & $\begin{array}{l}\text { Health and wellbeing, economy } \\
\text { and society, infrastructure and } \\
\text { ecosystem, leadership and strategy. }\end{array}$ & $\begin{array}{l}\text { Developed to assess the strength and weaknesses } \\
\text { in city resilience. It proposes the use of objective } \\
\text { and subjective methods. }\end{array}$ \\
\hline$[10]$ & $\begin{array}{l}\text { Climate Disaster } \\
\text { Resilience Index (CDRI). }\end{array}$ & $\begin{array}{l}\text { Economic, institutional, } \\
\text { natural, physical and social. }\end{array}$ & $\begin{array}{l}\text { Developed and tested in Chennai city while employing } \\
\text { subjective data collected at the zonal level. The authors } \\
\text { indicate that better results would have been got if the } \\
\text { assessment was conducted at household level. The study } \\
\text { reported low resilience in old city areas and high } \\
\text { resilience in new city areas thus important for planners. }\end{array}$ \\
\hline [3] & $\begin{array}{l}\text { Integrated Urban } \\
\text { Resilience Index (IURI). }\end{array}$ & Social, human and physical. & $\begin{array}{l}\text { It employed objective and subjective methods to } \\
\text { measure quality of life, people's happiness and } \\
\text { environmental sustainability before and after a } \\
\text { disaster. Resilience qualities such as robustness, } \\
\text { redundancy, efficiency and durability were observed. }\end{array}$ \\
\hline
\end{tabular}




\section{Continued}

$\begin{array}{lll}\text { [13] Urban Resilience } & \begin{array}{l}\text { Business, land use, food sources, } \\ \text { self-sufficiency and space for } \\ \text { citizen participation. }\end{array} & \begin{array}{l}\text { Developed to assess socio-ecological urban resilience of } \\ \text { Spanish cities. Objective methods at city level were used } \\ \text { and resilience qualities measured were diversity } \\ \text { and sufficiency. The study called for more efforts } \\ \text { to improve resilience in Spanish cities. }\end{array}\end{array}$

(b)

\begin{tabular}{cll}
\hline Author & \multicolumn{1}{c}{ Index } & \multicolumn{1}{c}{ Dimensions } \\
\hline$[6]$ & Urban Design & Ecological, physical, \\
& Resilience Index (UDRI). & functional and spatial.
\end{tabular}

[9] Spatial Disaster Assessment Model of Social Resilience (SDAMSR).

[20] Resilience Index for Urban Drainage Systems (RIUDS).

[14] Flood Disaster Resilience Index (FDRI).

[29] Climatic Hazard Resilience Indicator for Localities (CHRIL).

[1] Flood Risk Index (FRI).

[30] Integrated Flood Resilience Index (FResI).

[12] Socio-ecological Index (SI).

[11] Integrated Resilience Index (IRI). Socio-economic, physical, institutional, emergency preparedness and climate change hazards.

[17] Towards Resilience and Sustainable Disaster mitigation and City Adaptation Index (TRSCAI). adaptation, technological innovation and spatial management.
Human, community, economic and organizational.

Residential, agricultural and industrial areas.

Governance, economic, natural, physical and social.

Biophysical, socioeconomic, institutional, infrastructural, adaptive capacity and learning.

Social, economic, physical, natural and institutional.

Flood depth, flood duration, dwelling density, income per capita and sanitation.

Social, ecological, infrastructural, economic and institutional.
Details

It explains how the design of the urban form can be used to enhance resilience using objective methods at city scale. Resilience qualities observed were harmony with nature, diversity and connectivity.

Developed to measure the spatial heterogeneity of social attributes that relate to disaster damage in Seoul city using objective methods. Areas with high population and persons with disability were reported to be the least resilient.

Developed to assess the magnitude of flood damage in Jeongup city to inform flood control strategies.

The relationship between flood volume and damage were derived using objective methods.

Developed to assess resilience of Alexandria and Jakarta cities using objective and subjective methods. The index showed a need for improved adaptive capacity and planned urban systems.

Developed to guide planners in streamlining urban land use policies that could enhance resilience in Taichung city. It employed objective and subjective methods and the qualities observed include rapidity, redundancy, resourcefulness and robustness. It accounted for low resilience in some locations forming a basis for resource allocation.

It looks at the effectiveness of current urban management practices in improving resilience in Europe and Asian cities using subjective methods.

Developed to aid better flood management design alternatives for futures climate scenarios that overwhelm current standards in Rio de Janeiro city. The study used objective data and showed that sustainable urban drainage measures and river restoration techniques are the best alternatives.

Developed to map and quantify the spatial distribution of flood resilience in Eden district in South Africa. The study used objective data and qualities such as diversity, redundancy and connectivity were observed. It reported higher resilience at city center than at the periphery.

Developed to assess the current and future resilience of urban areas in the Nile Delta using objective methods. The study reported that 11 out of the 18 urban areas in the Nile Delta will suffer from floods.

Developed to assess the resilience of Jakarta city in Indonesia. Data was collected using subjective methods. The study reported that orderly management of space and improving community adaptive capacity was needed. 
(c)

\begin{tabular}{|c|c|c|c|}
\hline Author & Index & Dimensions & Details \\
\hline [16] & $\begin{array}{l}\text { Spatial Heat } \\
\text { Resilience Index (SHRI). }\end{array}$ & $\begin{array}{l}\text { Climate parameters, } \\
\text { adaptive clothing, } \\
\text { outdoor activities and } \\
\text { urban surface covers. }\end{array}$ & $\begin{array}{l}\text { It looks at the resilience of outdoor activities to heat } \\
\text { in cities of Sydney, Melbourne and Adelaide. Objective } \\
\text { and subjective methods were used. They reported that } \\
\text { outdoor activities decrease when thermal thresholds } \\
\text { of } 28^{\circ} \mathrm{C}-32^{\circ} \mathrm{C} \text { is reached and no activities occur } \\
\text { at a range of } 33^{\circ} \mathrm{C}-48^{\circ} \mathrm{C} \text {. }\end{array}$ \\
\hline [15] & $\begin{array}{l}\text { Integrated Regional } \\
\text { Resilience Framework (IRRF). }\end{array}$ & $\begin{array}{l}\text { Supply, demand and } \\
\text { adaptive capacity. }\end{array}$ & $\begin{array}{l}\text { Developed to assess the resilience capacity of San } \\
\text { Francisco to droughts. It used objective data to study } \\
\text { the supply, demand and adaptive capacity of the city } \\
\text { water management to droughts in order to inform } \\
\text { resilience strategies. Resilience qualities such as } \\
\text { sufficiency and diversity of water systems were observed. } \\
\text { They concluded that community level characteristics are } \\
\text { important in designing resilience strategies. }\end{array}$ \\
\hline
\end{tabular}

A synthesis of dimensions used by indices (Table 1) revealed that the social dimension was used by 10 indices, economic dimension (8), physical (7), institutional (7), ecological (7), adaptive capacity (5), governance (2), emergency preparedness (1) and exposure (1). Only 7 indices used dimensions that closely conform to those proposed by UNISDR [31], Sendai framework for action 2015-2030 and IPCC [32]. This implies that most indices deviate from the generally and globally accepted dimensions of resilience. This could be because they were developed for specific purposes, context and field of study. Even among resilience indices developed to measure a particular climate change shock like floods, there exists variance in the dimensions and variables considered. This makes it difficult for researchers in the same discipline to formulate appropriate research questions and resolve resilience baselines [33].

A synthesis of qualities commonly used to observe resilience revealed that 7 out of the 17 indices bring out clearly the qualities of resilience observed (Table 1). The rest of the indices seem not to bring out clearly these qualities which are indeed important in monitoring a systems resilience [3] [6]. The most observed qualities were redundancy, inclusiveness, robustness, flexibility, resourcefulness and integrated. Redundancy is having spare capacity to accommodate disruptions, inclusive is broad consultation and engagement of stakeholders and robustness is having well-constructed and well managed physical assets that can withstand shocks and stresses [28]. Flexibility is the ability to change, evolve and adapt in response to a disturbance, resourcefulness is the ability to find different ways of achieving goals while integrated is exchange of information between systems supportive to common outcomes [12] [28] [29].

Analysis of the scale of the urban areas for which the resilience indices were developed and applied (Table 1 ) revealed that all indices were developed to assess resilience at city and metropolitan levels and none for municipalities and townships. In addition, there was limited capturing of data at household level. However, Joerin [10] who captured data at zonal level indicated that they could have got better results if the assessment was conducted at household level. 
Analysis of the methods of data collection (Table 1) showed that out of the 17 indices, 9 used objective or secondary methods of data collection, 3 used subjective (primary) methods while, 5 used both objective and subjective methods. Subjective based methods are important because a person's resilience does not only constitute his tangible objective livelihood assets but also psychological, such as social networks, sense of place, beliefs and cultural identity [22] [34]. They also help in identifying improvements in resilience over time using consistent assessors, measuring the marginal effect of a resilience enhancement strategy and promoting the use of local knowledge in climate change risks assessment [33] [35]. On the other hand, using objective based measurements is faster due to their use of robust socio-economic and bio-physical secondary data. They reduce inter-assessor bias and offer high level of generalization [28]. However, objective data sets are often lacking in most developing countries making subjective methods suitable in such localities. Both subjective and objective based methods have their own strengths and weaknesses [28].

Out of the 17 indices synthesized, 8 indices that have dimensions and variables related to the physical, social, economic and institutional factors were selected (Table 2) [36] [37]. The indices selected include: The CDRI [10], IRI [11], SI [12], FDRI [14], FRI [1], CHRIL [29], SDAMSR [9] and CRI [23]. The variables obtained from the indices selected were used to validate the variables that were obtained from community perceptions on the most important components in resilience building in Mbale municipality in the previous study [38]. These formed the basis for proposing a context specific municipality resilience index that was used to quantify resilience against climate change shocks and stresses in Mbale municipality in Eastern Uganda with limited robust bio-physical and socio-economic data.

Table 2. Dimensions, indicators and variables derived from community perceptions and those listed by the eight selected indices that relate to the proposed MRI.

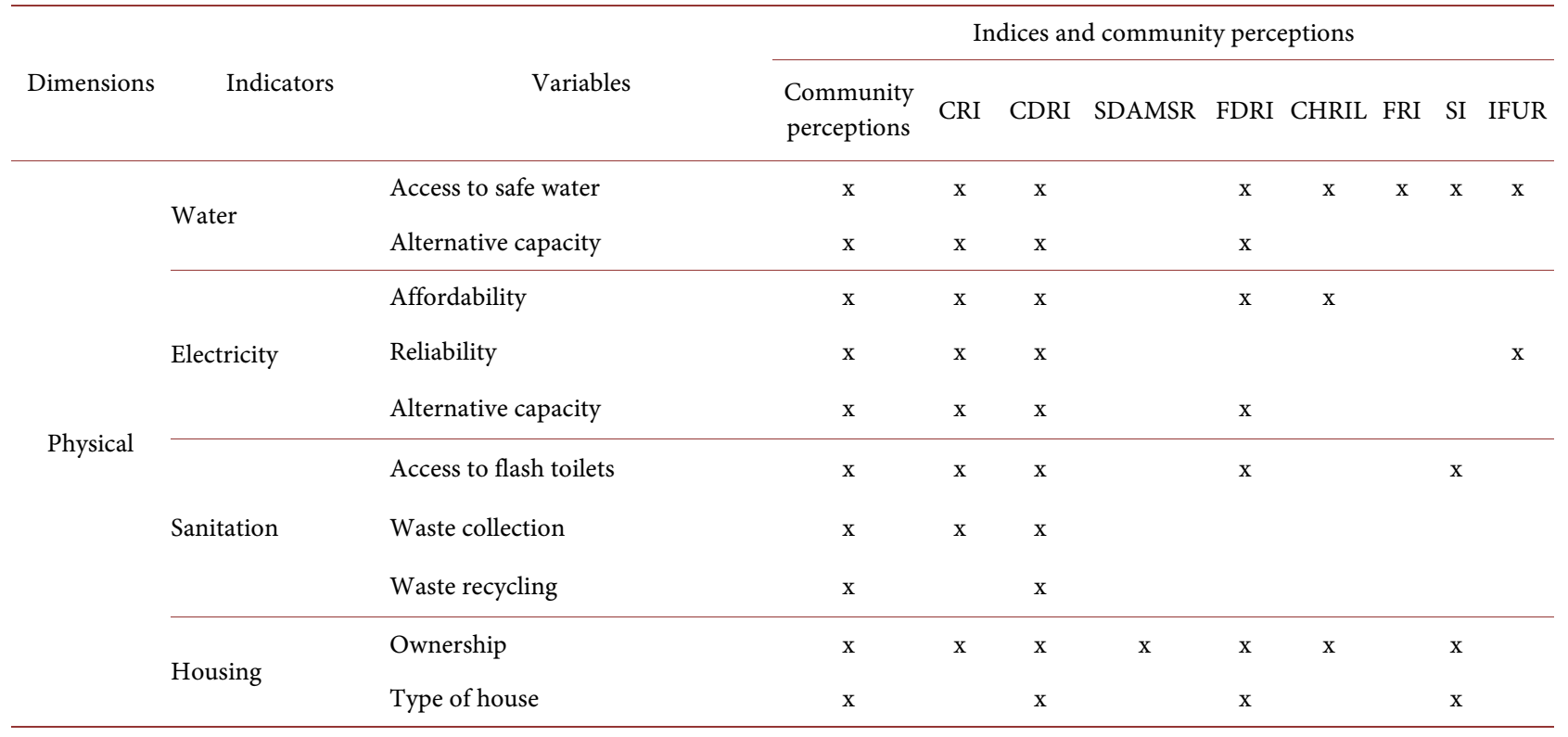




\begin{tabular}{|c|c|c|c|c|c|c|c|c|c|c|c|}
\hline & & $\begin{array}{l}\text { Ability to withstand shocks } \\
\text { and stresses (safety) }\end{array}$ & $\mathrm{x}$ & $\mathrm{x}$ & $\mathrm{x}$ & & & & & & \\
\hline & & Affordability & $\mathrm{x}$ & $\mathrm{x}$ & $\mathrm{x}$ & & & & & & $\mathrm{x}$ \\
\hline & & Access to roads & $\mathrm{x}$ & $\mathrm{x}$ & $\mathrm{x}$ & & & & & & \\
\hline & Transportation & Accessibility during heavy rains & $\mathrm{x}$ & & $\mathrm{x}$ & & & & & & \\
\hline & & Road side covered drains & $\mathrm{x}$ & $\mathrm{x}$ & $\mathrm{x}$ & & & & & & \\
\hline & & Crops & $\mathrm{x}$ & & & & & & & & \\
\hline & & Television & $\mathrm{x}$ & $\mathrm{x}$ & $\mathrm{x}$ & & & & $\mathrm{x}$ & $\mathrm{x}$ & \\
\hline & $\begin{array}{l}\text { Physical } \\
\text { assets }\end{array}$ & Radio & $\mathrm{x}$ & $\mathrm{x}$ & $\mathrm{x}$ & & & & & & \\
\hline & & Mobile phone & $\mathrm{x}$ & $\mathrm{x}$ & $\mathrm{x}$ & & & & $\mathrm{x}$ & $\mathrm{x}$ & \\
\hline & & Motorized vehicle & $\mathrm{x}$ & $\mathrm{x}$ & $\mathrm{x}$ & & $\mathrm{x}$ & & $\mathrm{x}$ & $\mathrm{x}$ & \\
\hline \multirow{11}{*}{ Social } & & Level of education & $\mathrm{x}$ & $\mathrm{x}$ & $\mathrm{x}$ & & $\mathrm{x}$ & $\mathrm{x}$ & $\mathrm{x}$ & $\mathrm{x}$ & \\
\hline & & Quality of education & $\mathrm{x}$ & $\mathrm{x}$ & & & & & & & \\
\hline & Education & Affordability & $\mathrm{x}$ & $\mathrm{x}$ & & & & & & & \\
\hline & & $\begin{array}{l}\text { Climate change } \\
\text { training programs }\end{array}$ & $\mathrm{x}$ & $\mathrm{x}$ & $\mathrm{x}$ & & & & & & $\mathrm{x}$ \\
\hline & & Access to health care & $\mathrm{x}$ & & $\mathrm{x}$ & $\mathrm{x}$ & $\mathrm{x}$ & & & & \\
\hline & Health & Stockpiles for emergencies & $\mathrm{x}$ & $\mathrm{x}$ & $\mathrm{x}$ & & & & & & $\mathrm{x}$ \\
\hline & & Good health & $\mathrm{x}$ & $\mathrm{x}$ & $\mathrm{x}$ & & & & & & \\
\hline & & Networks with NGO's & $\mathrm{x}$ & & & & & & & & $\mathrm{x}$ \\
\hline & Social safety & Networks with friends & $\mathrm{x}$ & & & & & & & & \\
\hline & networks & Networks with relatives & $\mathrm{x}$ & & & & & & & & \\
\hline & & Networks with government & $\mathrm{x}$ & $\mathrm{x}$ & & & & & & & $\mathrm{x}$ \\
\hline \multirow{8}{*}{ Economic } & & Monthly income & $\mathrm{x}$ & & & $\mathrm{x}$ & $\mathrm{x}$ & $\mathrm{x}$ & & $\mathrm{x}$ & \\
\hline & & Alternative income sources & $\mathrm{x}$ & $\mathrm{x}$ & $\mathrm{x}$ & & & $\mathrm{x}$ & & & \\
\hline & Finance & Savings & $\mathrm{x}$ & $\mathrm{x}$ & $\mathrm{x}$ & & & $\mathrm{x}$ & & & \\
\hline & & Access to credit & $\mathrm{x}$ & $\mathrm{x}$ & $\mathrm{x}$ & & & & & & \\
\hline & & Employment & $\mathrm{x}$ & $\mathrm{x}$ & $\mathrm{x}$ & $\mathrm{x}$ & $\mathrm{x}$ & & & $\mathrm{x}$ & $\mathrm{x}$ \\
\hline & & Pensions & $\mathrm{x}$ & & & & & & & & \\
\hline & $\begin{array}{l}\text { Economic } \\
\text { assets }\end{array}$ & Remittances & $\mathrm{x}$ & $\mathrm{x}$ & & & & & & & \\
\hline & & Insurance & $\mathrm{x}$ & $\mathrm{x}$ & $\mathrm{x}$ & & & & & & \\
\hline \multirow{5}{*}{ Institutional } & \multirow{5}{*}{$\begin{array}{l}\text { Good } \\
\text { governance }\end{array}$} & Exposure assessment & $\mathrm{x}$ & $\mathrm{x}$ & & & & $\mathrm{x}$ & & & $\mathrm{x}$ \\
\hline & & Vulnerability assessment & $\mathrm{x}$ & $\mathrm{x}$ & & & & & & & \\
\hline & & Ecosystem protection & $\mathrm{x}$ & $\mathrm{x}$ & & & $\mathrm{x}$ & $\mathrm{x}$ & $\mathrm{x}$ & $\mathrm{x}$ & \\
\hline & & $\begin{array}{l}\text { Stakeholders involvement in } \\
\text { disaster management plans }\end{array}$ & $\mathrm{x}$ & $\mathrm{x}$ & $\mathrm{x}$ & & $\mathrm{x}$ & & & $\mathrm{x}$ & \\
\hline & & Building codes and standards & $\mathrm{x}$ & $\mathrm{x}$ & $\mathrm{x}$ & & $\mathrm{x}$ & & $\mathrm{x}$ & & \\
\hline
\end{tabular}




\begin{tabular}{|c|c|c|c|c|c|c|c|c|c|}
\hline & $\begin{array}{l}\text { Implementation of climate } \\
\text { change management plans }\end{array}$ & $\mathrm{x}$ & $\mathrm{x}$ & & & & & & \\
\hline & Disaster preparedness plans & $\mathrm{x}$ & & & $\mathrm{x}$ & & & & $\mathrm{x}$ \\
\hline & $\begin{array}{l}\text { Representation of } \\
\text { marginalized groups of people }\end{array}$ & $\mathrm{x}$ & $\mathrm{x}$ & & & & & & \\
\hline \multirow{4}{*}{$\begin{array}{l}\text { Population } \\
\text { awareness }\end{array}$} & Early warnings & $\mathrm{x}$ & $\mathrm{x}$ & $\mathrm{x}$ & $\mathrm{x}$ & $\mathrm{x}$ & & & $\mathrm{x}$ \\
\hline & $\begin{array}{l}\text { Climate change } \\
\text { awareness programs }\end{array}$ & $\mathrm{x}$ & $\mathrm{x}$ & $\mathrm{x}$ & $\mathrm{x}$ & & \multirow{3}{*}{$\mathrm{x}$} & \multirow{3}{*}{$\mathrm{x}$} & $\mathrm{x}$ \\
\hline & Trained emergency teams & $\mathrm{x}$ & $\mathrm{x}$ & $\mathrm{x}$ & & & & & $\mathrm{x}$ \\
\hline & Emergency centers & $\mathrm{x}$ & $\mathrm{x}$ & $\mathrm{x}$ & $\mathrm{x}$ & & & & $\mathrm{x}$ \\
\hline
\end{tabular}

Summarily, most urban resilience indices either focus on the physical assets viewpoint while disregarding the intangible assets such as the social capital and safety nets [22], while others focus on adaptive capacity which views an urban area as a system encapsulating the physical, social, economic and institutional dimensions [11]. This study views an urban area as a complex system comprising of the social, economic, physical and institutional dimensions and thus, the complex adaptive systems theory was used to anchor this piece of work to make it possible to estimate resilience of Mbale municipality [39] [40]. Further still, household resilience capacities are process-oriented and context specific [22] [34]. Therefore attempts to measure resilience of households need to recognise people's intangible assets and their perceptions of resilience in the face of shocks and stresses while recognizing the existing indices [41]. This can offer deeper explanations and thus solutions than currently possible.

\section{Methods and the Approach}

In this section, the selection of the study area, forming the proposed index, data collection and analysis methods are presented.

\subsection{Study Area}

The study was conducted in Mbale municipality in Eastern Uganda from July to August 2017 (Figure 1). Mbale municipality comprises of three divisions i.e. Wanale, Industrial and Northern divisions constituted by 14 wards/parishes with a total population of 92,857 [42]. The municipality was selected based on its location in the mountainous disaster prone area characterised with recurring flash floods, prolonged droughts and high rate of urban population growth and density which impose pressure on land and social service provision [42] [43].

The municipality experiences a humid tropical climate with bimodal rainfall from March to June and from September to November, while the dry seasons spans between December to February and in July [44]. The average total annual rainfall was $1500 \mathrm{~mm}$ and the average annual temperature was $23^{\circ} \mathrm{C}$ for the period 1960-2009 [44]. Climate change is expected to increase the frequency and intensity of extreme events such as prolonged droughts, flash floods and heat waves in the municipality [44]. 


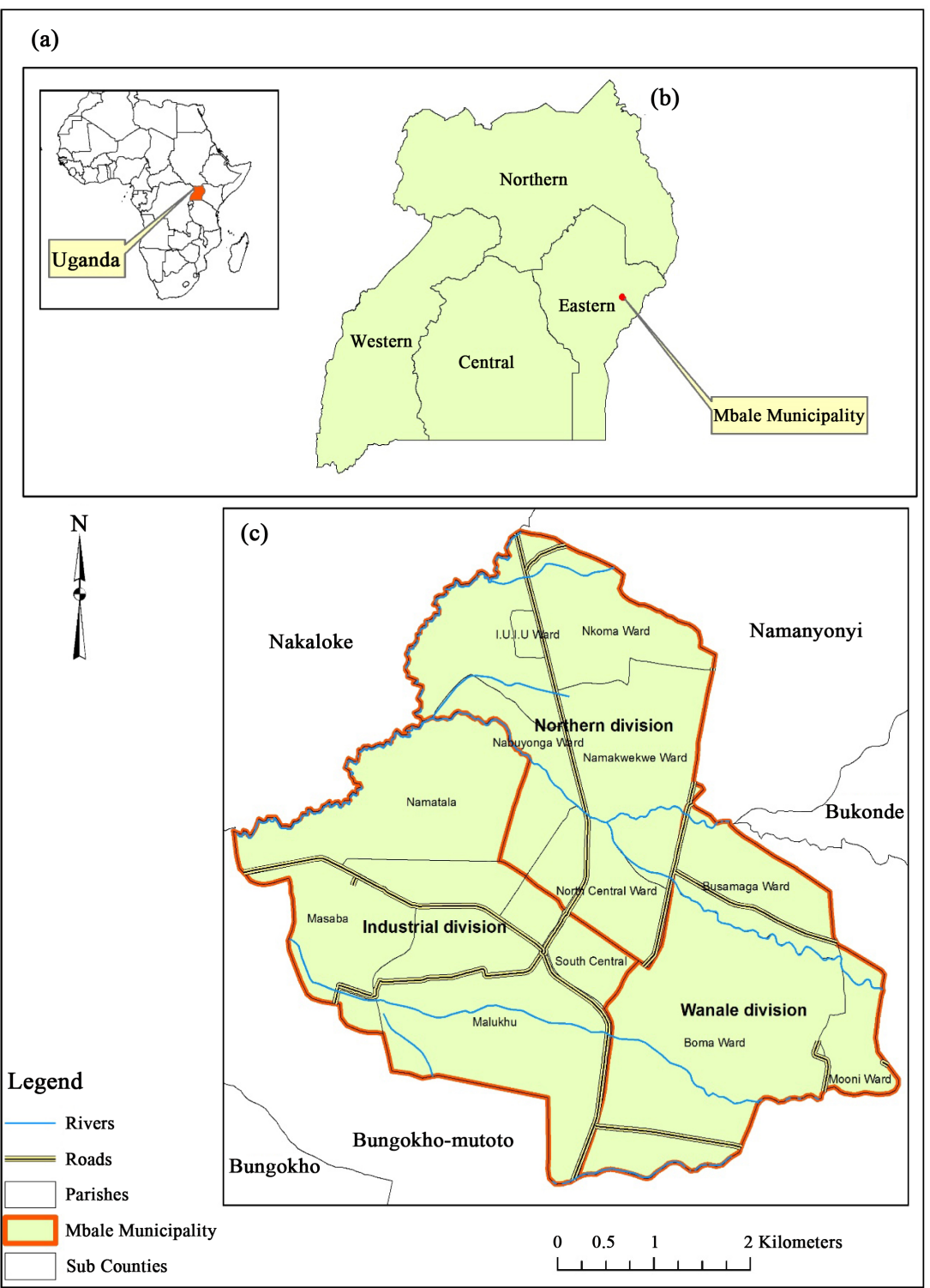

Figure 1. The study area location in Eastern Uganda. GIS generated map using UBOS 2014 shape files. (a) Uganda in Africa; (b) Mbale municipality in Uganda; (c) Mbale municipality.

\subsection{Forming the Proposed MRI for Climate Change Shocks and Stresses}

The study adopted the methodology of building a composite index put forward by Nardo and his colleagues [36] and OECD [37]. The methodology has severally been used [11] [12] [13] [23]. This methodology involves selection of an appropriate spatial scale, appropriate dimensions, indicators and variables to be measured.

\subsection{Selection of Appropriate Spatial Scale, Dimensions, Indicators and Variables}

The scale of a municipality was chosen since it is an administrative unit with 
normative competencies [13]. To come up with appropriate dimensions, indicators and variables that could measure urban resilience to climate related shocks and stresses in the context of Mbale municipality, the study draws from the previous study that used a participatory approach to come up with priority variables perceived to be important in enhancing community resilience in Mbale municipality [38] (Table 2). The expert views obtained from the reviewed indices helped to validate the variables that had been obtained from community perceptions. The selection of variables was based on accessibility, relevance and most repeated variables, while getting rid of those that are synonyms to obviate repetition [13] [37]. The variables were also selected basing on the following qualities of resilience that they measure: redundancy, inclusive, robustness and integrated [6] [12] [15] [28] as explained in this study sub section 1.2. The variables were then categorized into indicators and dimensions (Table 2).

The MRI constitutes 46 variables, 14 indicators and four dimensions (physical, social, economic and institutional) (Table 2). The physical dimension is selected because redundant, robust, flexible and inclusive physical infrastructure such as water, electricity, sanitation and transportation facilitates the well-functioning of an urban area, enhances people's ability to respond, absorb and recover easily when faced with climate change shocks and stresses [28]. The social dimension is selected because 1) robust and inclusive education sector can promote human development and enables people to easily understand early warnings which creates awareness about potential shocks and stresses. 2) Robust and inclusive health sector can support citizens to recover during and after shocks and stresses, while social safety networks among urban residents shows peoples connectedness to manage disturbances [10]. The economic dimension shows the ability of people to earn income to be able to meet the basic needs of life. It also shows the ability to save which provides the spare capacity that can be used during shocks and stresses [10]. The institutional dimension looks at the local and national government functioning to manage shocks and stresses. It constitutes good governance, population awareness and crisis management. Transparent, inclusive and integrated government planning helps to capture the diverse needs of the urban area for appropriate strategic planning. It also enables protection of important ecosystems which are essential in enabling the urban area to thrive during climate change chocks and stresses [28].

\subsection{Data Collection}

The MRI seeks to accommodate the context of Mbale municipality in Uganda where limited secondary data exists at household and municipal level. To reduce the challenge, 389 structured household interviews were conducted to get responses to the 46 variables (Table 3 ) in Industrial, Northern and Wanale divisions of Mbale municipality. The unit of analysis was a household. Household survey was conducted based on a multi-stage sampling procedure. This was due to its high level of flexibility, cost effectiveness, accommodating more than two sampling stages and sampling methods required [45]. The first stage involved a 
Table 3. Resilience dimensions in bold, indicators in italics and variables and their definitions in normal font.

\begin{tabular}{|c|c|c|c|}
\hline \multicolumn{2}{|l|}{ Physical: Water } & \multicolumn{2}{|l|}{ Economic: Finance } \\
\hline$\overline{\mathrm{W} \_ \text {access }}$ & Accessibility throughout the year $(\mathrm{Y} / \mathrm{N})$ & M_income & Monthly income (scale) \\
\hline W_safety & Water safety during heavy rainfall events $(\mathrm{Y} / \mathrm{N})$ & Alt_income & Alternative income $(\mathrm{Y} / \mathrm{N})$ \\
\hline W_alt_capacity & $\begin{array}{l}\text { Alternative capacity during } \\
\text { prolonged droughts }(\mathrm{Y} / \mathrm{N})\end{array}$ & Savings & Having savings $(\mathrm{Y} / \mathrm{N})$ \\
\hline \multicolumn{2}{|l|}{ Electricity } & Acc_credit & Having access to credit $(\mathrm{Y} / \mathrm{N})$ \\
\hline El_access & Accessibility $(\mathrm{Y} / \mathrm{N})$ & Occupation & Primary occupation (scale) \\
\hline El_reliab & Reliability (Y/N) & Remittances & Access to remittances $(\mathrm{Y} / \mathrm{N})$ \\
\hline El_alt.capacity & Alternative capacity $(\mathrm{Y} / \mathrm{N})$ & \multicolumn{2}{|l|}{ Economic assets } \\
\hline \multicolumn{2}{|l|}{ Sanitation } & Pension & Access to pension $(\mathrm{Y} / \mathrm{N})$ \\
\hline Own_toilet & Owning flash toilet/latrines $(\mathrm{Y} / \mathrm{N})$ & Insur_cover & Access to insurance $(\mathrm{Y} / \mathrm{N})$ \\
\hline Con_reliab_sewage & Connected to reliable sewage network $(\mathrm{Y} / \mathrm{N})$ & \multicolumn{2}{|l|}{ Institutional } \\
\hline Div_waste_mgt & Diverse waste management $(\mathrm{Y} / \mathrm{N})$ & \multicolumn{2}{|l|}{ Good governance } \\
\hline \multicolumn{2}{|l|}{ Housing } & Identi_vulnerable & $\begin{array}{l}\text { Identification of Vulnerable groups } \\
\text { (5-point Likert scale) }\end{array}$ \\
\hline Acc_shelter & $\%$ Access & Eco_protection & $\begin{array}{l}\text { Ecosystem protection } \\
\text { (5-point Likert scale) }\end{array}$ \\
\hline Troof & Type of roof $(\mathrm{Y} / \mathrm{N})$ & \multirow[t]{2}{*}{ Stakeholder_involvement } & $\begin{array}{l}\text { Stakeholder involvement in } \\
\text { decision making }\end{array}$ \\
\hline Twall & Type of wall $(\mathrm{Y} / \mathrm{N})$ & & (5-point Likert scale) \\
\hline Tfloor & Type of floor (Y/N) & Clim_Spreparedness & $\begin{array}{l}\text { Preparedness plans against shocks } \\
\text { and stresses (5-point Likert scale) }\end{array}$ \\
\hline Ab_Wshorks & $\%$ ability to withstand storms & Repres_marginalized & $\begin{array}{l}\text { Representation of marginalized } \\
\text { groups (5-point Likert scale) }\end{array}$ \\
\hline \multicolumn{2}{|l|}{ Transportation } & Authority_Dclimate_change & $\begin{array}{l}\text { Authority dealing with climate } \\
\text { change shocks and stresses } \\
\text { (5-point Likert scale) }\end{array}$ \\
\hline Acc_roads & $\%$ accessibility of roads during heavy rains & \multicolumn{2}{|l|}{ Population awareness } \\
\hline Ex_Rd.Drains & Existence of road side covered drains $(\mathrm{Y} / \mathrm{N})$ & Weather_Ewarnings & $\begin{array}{l}\text { Existence of weather early warnings } \\
\text { (5-point Likert scale) }\end{array}$ \\
\hline \multicolumn{2}{|l|}{ Physical assets } & Clim_awar_prgms & Climate change awareness programs \\
\hline Land_own & Owning land $(\mathrm{Y} / \mathrm{N})$ & \multicolumn{2}{|l|}{ Crisis management } \\
\hline Crop_own & Owning crops $(\mathrm{Y} / \mathrm{N})$ & Emergency_teams & $\begin{array}{l}\text { Existence of trained emergency } \\
\text { teams (5-point Likert scale) }\end{array}$ \\
\hline Adeq_nut_fd & Stock of adequate nutritious food $(\mathrm{Y} / \mathrm{N})$ & Emergency_facilities & $\begin{array}{l}\text { Existence of emergency facilities } \\
\text { (5-point Likert scale) }\end{array}$ \\
\hline Livestock_own & Ownership of livestock (Y/N) & & \\
\hline Means_cmntn_own & $\begin{array}{l}\text { Ownership of means of communication } \\
\text { (television, radio, phone) }(\mathrm{Y} / \mathrm{N})\end{array}$ & & \\
\hline \multicolumn{4}{|l|}{ Social } \\
\hline Education & & & \\
\hline
\end{tabular}




\section{Continued}

\begin{tabular}{ll}
\hline $\begin{array}{l}\text { Educ_level } \\
\text { Educ_quality }\end{array}$ & $\begin{array}{l}\text { Education level (scale) } \\
\text { \% Access to quality education }\end{array}$ \\
\hline Health & \\
\hline Acce_health & Access to health services (Y/N) \\
Health_stockpiles & Existence of stockpiles for emergencies during storms and heavy rainfall (Y/N) \\
Gd_health & \% having good health \\
\hline Social networks & \\
\hline N_NGO's & Networks with NGO's (Y/N) \\
N_relatives & Networks with relatives $(\mathrm{Y} / \mathrm{N})$ \\
N_friends & Networks with friends $(\mathrm{Y} / \mathrm{N})$ \\
N_Government & Networks with government $(\mathrm{Y} / \mathrm{N})$
\end{tabular}

$\mathrm{Y}=$ yes, $\mathrm{N}=$ no.

purposive selection of seven wards out of 14 wards in the three divisions. These wards were selected taking into consideration sensitivity and fragility of the wards to climate change shocks and stresses and population characteristics [44] [42]. The second stage involved random sampling of households while using a structured household interview questionnaire. Random sampling was deemed appropriate at this stage because every household in the selected wards are likely to be affected by climate change shocks and stresses, thus assumed to be uniform and selecting any household would be representative of the total population. The study sample size was statistically determined using Yamane's procedure [46] at a $5 \%$ level of precision.

Furthermore, the UBOS census figures of the seven sampled wards were used to proportionately distribute the 389 households in order to derive the exact figures to be sampled in each ward or parish (Figure 1). Consequently, in Malukhu ward 46 households were sampled, in Namatala ward 129, in Nabuyonga ward 50, in Namakwekwe ward 79, in Nkoma ward 58, in Boma ward 11 and in Busamaga west 19 households. Closed ended questions were used because they provide an expeditious instrument in data collection, coding, interpretation and quantification [22]. The data collection tool was pre-tested on 15 households after obtaining their consent. The data collected constituted of households' perceptions, knowledge and opinions regarding the availability and access to resilience variables. Two scales were used i.e., a binary scale where variables offer a choice between "0" (not available) and "1" (available) and a 5 point Likert scale that offers choices between "1" (strongly disagree), "2" (disagree), "3" (undecided), "4" (agree) and "5" (strongly agree).

\subsection{Calculation of the Municipality Resilience Index}

To compute the resilience index, the study draws from the method used by Freudenberg [47] and Nardo and his colleagues [36]. This method has been used by climate disaster resilience studies [14] [48]. First, it involves normalizing the variables since different measurement units and scales were used. Normalization 
enables variables to have a common basis and avoids the problems in mixing measurement units [47] [36]. Several normalization methods exist [36]. This study uses a rescaling "Min-max" normalization method that adjusts observed variables to take a value of 0 to 1 [36]. This normalization method has severally been used [14] [12] (Equations (1)).

$$
\text { Normalized Value }=\left(E_{i}-E_{\min }\right) /\left(E_{\max }-E_{\min }\right)
$$

where: $E_{i}$ is the observed variable, $E_{\min }$ is the minimum value of the observed variable, $E_{\max }$ is the maximum value of the observed variable.

Second, Principal Component Analysis (PCA) was used to assign weights to the normalized variables. This helps to reflect the contribution of each variable to the overall composite [48] [36]. In order to generate the resilience index, all variables are considered to have the same weights after normalization and therefore all are equally important in the final outcome of the MRI [14] [47]. Therefore, Equation (2) was used to combine variables to generate the resilience index of the dimensions [47] [14].

$$
y_{i}=\sum\left(X_{1} W_{1}+X_{2} W_{2}+X_{3} W_{3}+\cdots+X_{n} W_{n}\right)
$$

where: $y$ is the dimension of the resilience index, $X$ is any normalized variable, $W$ is the weight of any variable, $n$ is the number of the variable or weights considered and $i$ is the number of variables.

Third, to generate the overall Municipality Resilience Index of Mbale municipality, Equation (3) proposed by Mayunga [48] was used.

$$
M R I=\left(\sum\left(W_{1} P D_{i}+W_{2} S D_{i}+W_{3} E D_{i}+W_{4} I D_{i}\right)\right) / n
$$

where: $P D_{i}$ is the index of the physical dimension, $S D_{i}$ is the index of the social dimension, $E D_{i}$ is the index of the economic dimension, $I D_{i}$ is the index of the institutional dimension, $W$ is the weight, $\mathrm{n}$ is the number of variables in the dimensions and $i$ is the variable number.

\subsection{Limitations of the Index}

Measuring resilience requires complex indicators and variables and thus it is often a challenge for a single index to be able to capture all variables [33]. This index gives emphasis to using subjective methods which may limit generalization of results. However, attempts need to be made to visit secondary sources to obtain objective variables where data cannot be obtained from households. Despite the limitations, the study presents and tests an assessment index to understand urban resilience in a developing country. This is important because it can allow government or other organisations that seek to improve resilience over time using consistent assessors [33].

\section{Results and Discussion}

\subsection{The Average Resilience Scores of the Three Division in Mbale Municipality}

Overall, the resilience index of Mbale municipality is 0.2 . This implies a low resi- 
lience of the municipality to climate related shocks and stresses. This confirms reports that the municipality is located in a low socio-economically developed region of Uganda characterized by high level of vulnerability to climate related shocks and stresses [49]. In terms of the three divisions in the municipality (Figure 2), results revealed that, Industrial division has the highest average resilience score (1.7), followed by Northern division (0.9) and Wanale division $(-1.9)$. The relatively higher resilience score by Industrial division contradicts findings of the previous study in the municipality that focused on only the social dimension and reported that Industrial division was the least resilient [50]. However, the study finding confirms studies that argue that resilience can be well understood by exploring its multidimensional aspects rather than just a single dimension [10] [14].

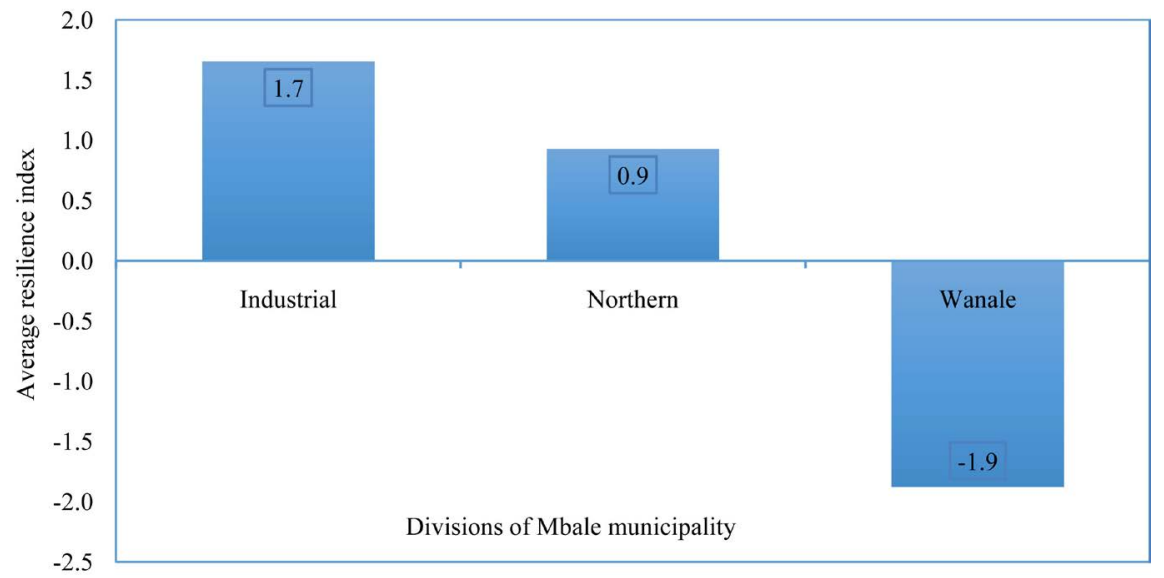

Figure 2. The average resilience index of the three divisions in Mbale municipality in Eastern Uganda in the year $2017(\mathrm{n}=389)$.

\subsection{Comparing the Performance of Resilience Dimensions in the Three Divisions}

Findings in Figure 3 show that the physical dimension performed quite well in Northern divisions with an average resilience index of 3.1 and so poorly in other divisions. The economic dimension performed quite well in Wanale division (3.7) and so poorly in other divisions. The institutional dimension performed quite well in Industrial division (4.7) and so poorly in other divisions. However, the social dimension performed poorly in all the divisions with an average resilience index of 1.7 in Industrial, 0.3 in Northern and -2.4 in Wanale. This findings imply that Northern division has achieved more of the physical factors such as access to water, electricity, housing and transport as compared to other factors while Industrial and Wanale divisions may not have achieved enough in providing the physical factors. Whereas, Wanale division has achieved more in the economic factors such as savings and credit as compared to other factors, it is the institutional dimension that has been well achieved in Industrial division. This could be because of the various government and non-governmental institutions that have been strengthened in Industrial division and this have been ap- 
preciated by the population. From these findings, it is clear that the contributions of the four dimensions towards the resilience index of Mbale municipality is spatially differentiated. They indicate non uniform strengths and weaknesses in performance in the three divisions. This is likely to be due to differing priorities given to different sectors by the local governments in the three divisions. The overall poor performance of the social dimension in all the divisions corroborates with the results by Kamh [14] who reported that the social dimension performed poorly towards the resilience index of Jakarta and Alexandria.

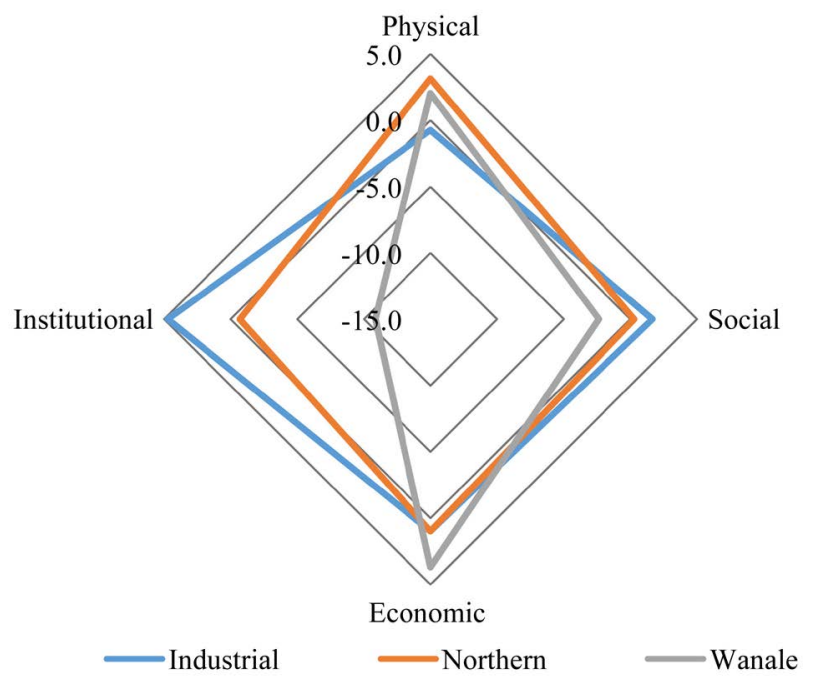

Figure 3. Comparison of the performance of the resilience dimensions towards the resilience index of the three divisions in Mbale municipality in Eastern Uganda ( $\mathrm{n}=389)$.

\subsection{The Performance of the Four Dimensions of the MRI towards the Resilience of Mbale Municipality}

Findings on the performance of the four dimensions of the MRI (Figure 4) revealed that the physical dimension scores 1.3 , economic (1.2), institutional (1.1) and the social (0.7). The relatively high score by the physical dimension as compared to other dimensions implies that household in the municipality have currently achieved more of the elements in the physical dimension i.e. access to electricity, water, transport, housing and sanitation. Furthermore, the least score by the social dimension may imply that livelihoods in the urban environment are less defined by the social variables. This relates to the finding by FAO-UNICEF-WPF [51] who reported the highest score by the physical dimension and the lowest score by the social dimension towards the resilience of urban livelihoods in Dolow in Somalia. However, this study finding contradicts the finding of Kotzee and Reyers [12] in Eden district in South Africa who reported that it was the social factors which had a high resilience score as compared to other factors. This variations could be a result of how much the different governments and other stake holders have injected towards the development of the different sectors and thus points towards where more efforts need to be vested to achieve a holistic and multidimensional resilience. 


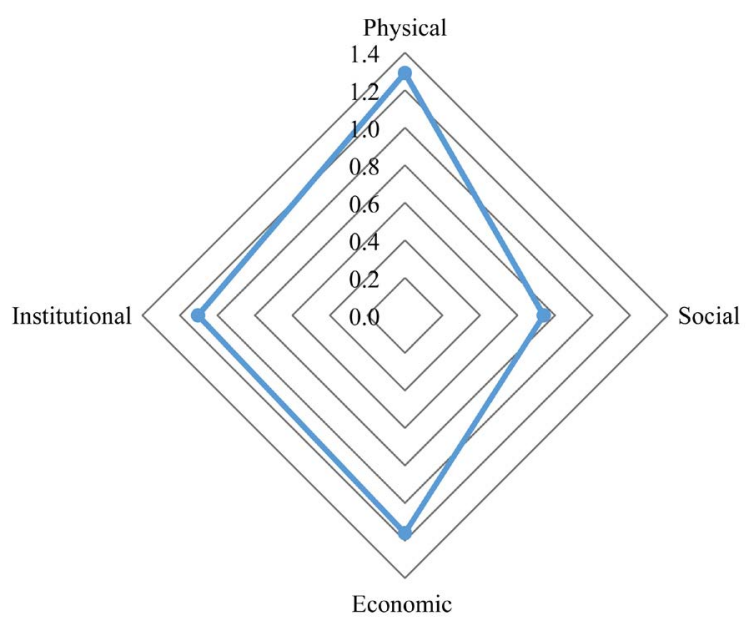

Figure 4. The overall contribution of the four dimensions towards the resilience index of Mbale municipality in Eastern Uganda $(\mathrm{n}=389)$.

\subsection{The Performance of the Variables in Each of the Four Dimensions of the MRI in Mbale Municipality}

The performance of the variables under the physical, social, economic and institutional dimensions are illustrated in Figures 5-8. In terms of the physical dimension (Figure 5), results generally revealed that access to water, ownership of toilets, diversity of waste management and housing highly contributed to the current household resilience while safety and alternative capacity of water, supply and reliability of electricity, connection to reliable sewage network, ownership of shelter, means of communication and adequate nutritious food were low contributors of current household resilience. This results give a picture on the contribution of each variable as shown by their factor loading. Factor loading indicate the relative statistical contribution of the observed variables in the resilience dimensions [51]. A high factor loading suggests that the variance of the latent variable is highly correlated to the absolute value of the observed variable. " $A$ variable with a high factor loading within a dimension that has a high factor loading in the resilience index is a variable which, if improved by one standard deviation unit would affect the resilience index most positively" [51]. While a low factor loading suggests a low correlation between the observed variable and the latent variable at given point in time. These indicate weak contributors to the current resilience index and may indicate variables which have consistently low values; however, the impact of an improvement on resilience could be important. For example, so few people in the sample have reliable electricity would not be correct to conclude that electricity is irrelevant [51].

Among the social variables (Figure 6), networks with: NGO's, relatives, friends and government have high factor loading as compared to the level and quality of education, access to health and health stockpiles to manage emergencies. Social networks have often been regarded as first responders during times of shocks and stresses because they can help provide gifts, loans, emotional support and early warnings which are important in enhancing peoples resilience 
[52] [53]. Networks with friends and relatives from the rural communities played an important role towards household resilience to food insecurity in $\mathrm{Ha}$ rare in Zimbabwe [54]. In the same vein, the resilience of urban refugees in Nairobi, Kenya was enhanced by establishing networks with NGO's particularly religious organisations [55].

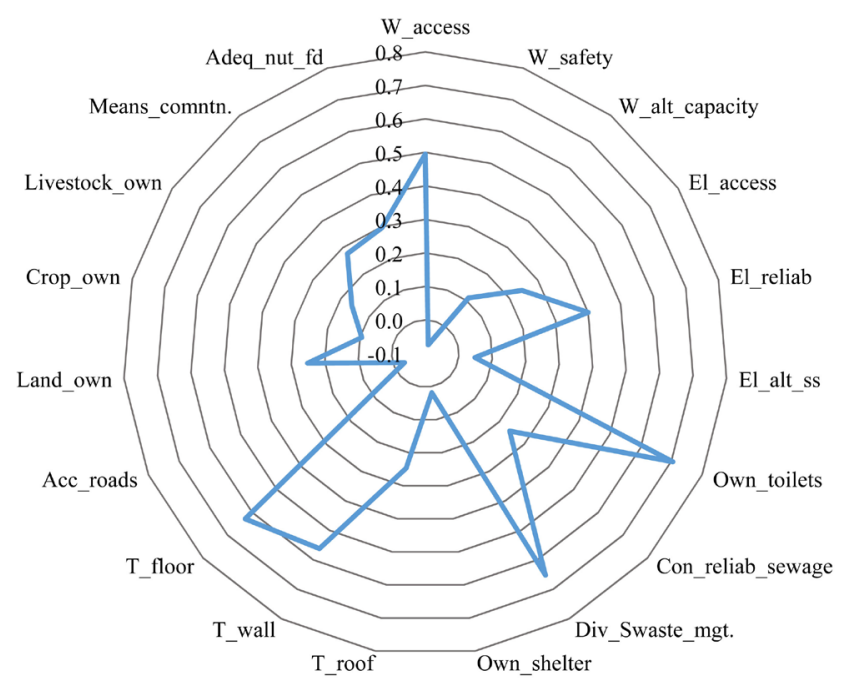

Figure 5. The performance of the variables in the physical dimension of the MRI in Mbale municipality in Eastern Uganda for the period $2017(\mathrm{n}=389)$.

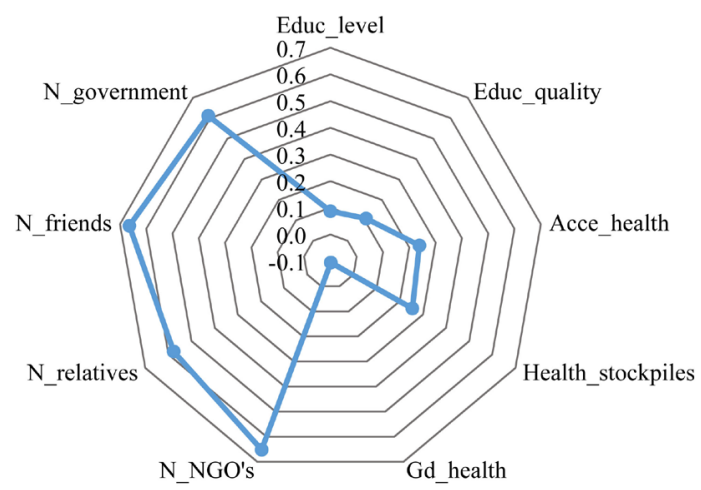

Figure 6. The performance of the variables in the social dimension of the MRI in Mbale municipality in Eastern Uganda for the period $2017(\mathrm{n}=389)$.

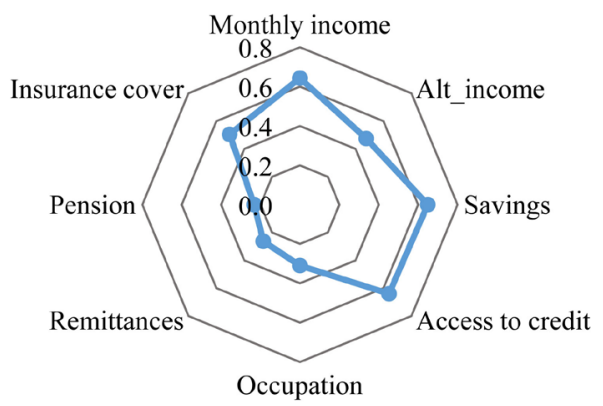

Figure 7. The performance of the variables in the economic dimension of the MRI in Mbale municipality in Eastern Uganda for the period $2017(\mathrm{n}=389)$. 


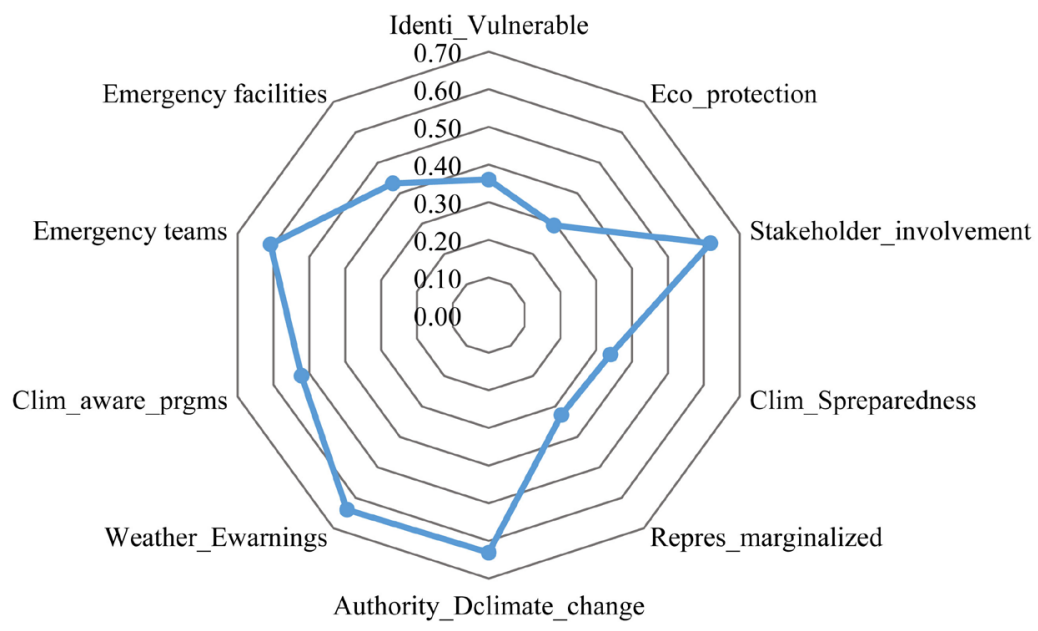

Figure 8. The performance of the variables in the institutional dimension of the MRI in Mbale municipality in Eastern Uganda for the period $2017(\mathrm{n}=389)$.

The performance of the variables under the economic dimension (Figure 7) revealed that monthly income, savings and access to credit have a high factor loading implying that households have achieved more in these variables as compared to alternative income sources, employment, remittances, pension and insurance cover. The high contribution by monthly income, savings and access to credit indicate that attempts by government and other stake holders to promote savings and credit have yielded progress and have been appreciated by households in improving their resilience. The importance of income and credit is always seen as stimulator for investment in income generating activities while savings act as a spare capacity to withstand shocks and stresses. Several studies have indicated the importance of income, access to credit and savings in enhancing household and community resilience [10] [29].

Under the institutional dimension (Figure 8), existence of an authority dealing in climate change, stakeholder involvement, climate awareness programs and early weather warnings relatively scored high, while ecosystem protection, representation of marginalized groups, vulnerability assessment and emergency facilities have very low scores. This reflects awareness about climate change shocks and stresses has been created and the population acknowledges this achievement while areas of good governance are still staggering in enabling the creation of a resilient Mbale municipality.

\section{Conclusions and Recommendations}

The proposed MRI includes 46 variables describing the physical, social, economic and the institutional dimensions. The MRI was tested in Mbale municipality to assess resilience to climate change shocks and stresses and the contribution of the four dimensions towards the resilience index. This index can be applied in municipalities of other developing countries with limited robust bio-physical and socio-economic data and with similar climate related challenges. 
Findings revealed that Industrial division has the highest resilience index as compared to Northern and Wanale divisions implying a spatial temporal differentiation of resilience even within a small geographic confine. When the performance of the four resilience dimensions in the three divisions was compared, the physical dimension performed well in Northern division, the economic dimension performed well in Wanale division, the institutional dimension performed well in Industrial division while, the social dimension performed poorly in all the three divisions. The variability in performance of the four dimensions based on the divisions reflects the different priorities given to different sectors and the gaps that exist in other sectors. This can guide the local government and other practitioners on which sectors to target in order to enhance resilience of households in Mbale municipality.

Although the overall performance of the four dimensions in the municipality indicates more achievement in the physical dimension and less in the social dimension, the overall performance of most of the variables in all the dimensions is very low. This implies low socioeconomic development in the municipality and thus the study gives the following insights that could be of interest for policy and practitioners:

- For the physical dimension, there is a need to improve safety and alternative capacity of water; reliability and alternative capacity of electricity; reliability of sewage network and means of communication.

- For the social dimension, there is a need to enhance the level and quality of education and health.

- In the economic dimension, an effort is needed to improve access to employment and insurance cover.

- Furthermore, an effort is needed in ecosystem protection, representation of marginalized groups of people, vulnerability assessment, climate change preparedness, climate change awareness programs and provision of emergency facilities to address the shortcomings of the institutional dimension.

\section{Acknowledgements}

The authors acknowledge the generous funding of this research by the Swedish International Development Agency (SIDA) under the Building Resilient Ecosystems and Livelihoods to Climate Change and Disaster Risks (BREAD) project, grant Number 331.

\section{Conflicts of Interest}

The authors declare no conflicts of interest regarding the publication of this paper.

\section{References}

[1] Batica, J. and Gourbesville, P. (2016) Resilience in Flood Risk Management: A New Communication Tool. Procedia Engineering, 154, 811-817.

https://doi.org/10.1016/j.proeng.2016.07.411 
[2] Pharoah, R. and Ross, S. (2015) Strengthening Climate Resilience in African Cities, Stellenbosch University.

[3] Bozza, A., Asprone, D. and Manfredi, G. (2015) Developing an Integrated Framework to Quantify Resilience of Urban Systems against Disasters. Natural Hazards, 78, 1729-1748. https://doi.org/10.1007/s11069-015-1798-3

[4] Hartman, T. and Tegi, S. (2014) Capacity Building for the Integration of Climate Adaptation into Urban Planning Processes: The Dutch Experience. American Journal of Climate Change, 3, 23.

[5] Hofit, I.S., Rana, S. and Oded, P. (2016) Recent Trends and Future Predictions until 2060 of Urban Warming in Four Israeli Cities Employing the RegCM Climate Model. American Journal of Climate Change, 5, 21.

[6] Dhar, T.K. and Khirfan, L. (2017) A Multi-Scale and Multi-Dimensional Framework for Enhancing the Resilience of Urban Form to Climate Change. Urban Climate, 19, 72-91. https://doi.org/10.1016/j.uclim.2016.12.004

[7] Wie, J.E., Considine, C. and Covi, M. (2017) Mechanisms for Cross-Scaling, Flexibility and Social Learning in Building Resilience to Sea Level Rise: Case Study of Hampton Roads, Virginia. American Journal of Climate Change, 6, 18.

[8] Lankao, P.R. (2011) Urban Areas and Climate Change: Review of Current Issues and Trends, Colorado.

[9] Chun, H., Chi, S. and Hwang, B.G. (2017) A Spatial Disaster Assessment Model of Social Resilience Based on Geographically Weighted Regression. Sustainability, 9, 2222-2238. https://doi.org/10.3390/su9122222

[10] Joerin, J., Shaw, R., Takeuchi, Y. and Krishnamurthy, R. (2014) The Adoption of a Climate Disaster Resilience Index in Chennai, India. Disasters, 38, 540-561. https://doi.org/10.1111/disa.12058

[11] Abdrabo, M.A. and Hassaan, M.A. (2015) An Integrated Framework for Urban Resilience to Climate Change-Case Study: Sea Level Rise Impacts on the Nile Delta Coastal Urban Areas. Urban Climate, 14, 554-565. https://doi.org/10.1016/j.uclim.2015.09.005

[12] Kotzee, I. and Reyers, B. (2016) Piloting a Social-Ecological Index for Measuring Flood Resilience: A Composite Index Approach. Ecological Indicators, 60, 45-53. https://doi.org/10.1016/j.ecolind.2015.06.018

[13] Suárez, M., Gómez, B.E., Benayas, J. and Tilbury, D. (2016) Towards an Urban Resilience Index: A Case Study in 50 Spanish Cities. Sustainability, 8, 19. https://doi.org/10.3390/su8080774

[14] Kamh, Y.Z., Khalifa, M.A. and El-Bahrawy, A.N. (2016) Comparative Study of Community Resilience in Mega Coastal Cities Threatened by Sea Level Rise: The Case of Alexandria and Jakarta. Procedia Social and Behavioral Sciences, 216, 503-517. https://doi.org/10.1016/j.sbspro.2015.12.007

[15] Gonzales, P. and Ajami, N.K. (2017) An Integrative Regional Resilience Framework for the Changing Urban Water Paradigm. Sustainable Cities and Society, 30, 128-138. https://doi.org/10.1016/j.scs.2017.01.012

[16] Sharifi, E. and Boland, J. (2017) Heat Resilience in Public Space and its Applications in Healthy and Low Carbon Cities. Procedia Engineering, 180, 944-954. https://doi.org/10.1016/j.proeng.2017.04.254

[17] Renald, A., Tjiptoherijanto, P., Suganda, E. and Deni, R. (2016) Towards Resilient and Sustainable City Adaptation Model for Flood Disaster Prone City: Case Study of Jakarta Capital Region. Procedia Social and Behavioral Sciences, 227, 334-340. https://doi.org/10.1016/j.sbspro.2016.06.079 
[18] Floater, N.J., Graham, P.R., Alexis, R., Kennedy, C., Hoornweg, D. and Slavcheva, R. (2014) Cities and the New Climate Economy: The Transformative Role of Global Urban Growth, London.

[19] Forino, G., MacKee, J. and Von Meding, J. (2016) A Proposed Assessment Index for Climate Change-Related Risk for Cultural Heritage Protection in Newcastle (Australia). International Journal of Disaster Risk Reduction, 19, 235-248. https://doi.org/10.1016/j.ijdrr.2016.09.003

[20] Lee, H.E. and Kim, J.H. (2017) Development of Resilience Index Based on Flooding Damage in Urban Areas. Water (Switzerland), 9, 1-15. https://doi.org/10.3390/w9060428

[21] Mugume, S.N., Gomez, D.E., Fu, G., Farmani, R. and Butler, D. (2015) A Global Analysis Approach for Investigating Structural Resilience in Urban Drainage Systems. Water Research, 81, 15-26. https://doi.org/10.1080/1573062X.2016.1253754

[22] Jones, L. and Tanner, T. (2015) Measuring “Subjective Resilience” Using People’s Perceptions to Quantify Household Resilience, Overseas Development Intitute. https://doi.org/10.2139/ssrn.2643420

[23] The Rockefeller Foundation/Arup. (2014) City Resilience Index. Research Report Volume 3, Urban Measurement Report, New York.

[24] Holling, C.S. (1973) Resilience and Stability of Ecological Systems. Annual Review of Ecology and Systematics, 4, 1-23. https://doi.org/10.1146/annurev.es.04.110173.000245

[25] Holling, C.S. (1996) Engineering Resilience versus Ecological Resilience. In: Engineering within Ecological Constraints, National Academies Press, Washington DC, 31-44. https://doi.org/10.17226/4919

[26] UNISDR (2015) Making Development Sustainable: The Future of Disaster Risk Management. Global Assessment Report on Disaster Risk Reduction, New York.

[27] UNU-CPR (United Nations University Centre for Policy Research) (2016) Defining the Resilient City. Washington DC.

[28] The Rockefeller Foundation/Arup. (2016) Measuring City Resilience, New York.

[29] Hung, H.C., Yang, C.Y., Chien, C.Y. and Liu, Y.C. (2016) Building Resilience: Mainstreaming Community Participation into Integrated Assessment of Resilience to Climatic Hazards in Metropolitan Land Use Management. Land Use Policy, 50, 48-58. https://doi.org/10.1016/j.landusepol.2015.08.029

[30] Miguez, M.G. and Verol, A.P. (2016) A Catchment Scale Integrated Flood Resilience Index to Support Decision Making in Urban Flood Control Design. Urban Analytics and City Science, 44, 926-946. https://doi.org/10.1177/0265813516655799

[31] UNISDR (2008) Climate Change and Disaster Risk Reduction. Geneva.

[32] IPCC (2014) Climate Change 2014. Synthesis Report: Summary Chapter for Policymakers, New York.

[33] Edwads, P., Cole, B., Tesh, J., Cameron, J., Albrito, H., Newnham, P., Crask, C., Vallejo, J., Sperrin, L., Watson, M., Home, J., Pretson, R., Branicki, J., Kalawski, I. and Binner, J. (2013) Measuring the Resilience of Cities: The Role of Big Data. Proceedings of the Conference of Measuring the Resilience of Cities. The Role of Big Data, 25 October 2013, 1-143.

[34] Wong-Parodi, G., Fischhoff, B. and Strauss, B. (2015) Resilience vs. Adaptation: Framing and Action. Climate Risk Management, 10, 1-7.

https://doi.org/10.1016/j.crm.2015.07.002

[35] Choptiany, J.M.H., Phillips, P., Graeub, B.E., Colozza, D., Settle, W., Herren, B. and 
Batello, C. (2017) Integrating a Traditional Survey with Participatory Self-Evaluation and Learning for Climate Change Resilience Assessment. Climate and Development, 9, 505-517. https://doi.org/10.1080/17565529.2016.1174661

[36] Nardo, M., Saisana, M., Saltelli, S., Tarantola, A., Hoffman, A. and Giovannini, E. (2008) Handbook on Constructing Composite Indicators: Methodology and User Guide. OECD Statistics Working Papers, 2005/^3, OECD Publishing, Paris. https://doi.org/10.1787/9789264043466-en

[37] OECD (2008) Handbook on Constructing Composite Indicators: Methodology and User Guide. OECD Publishing, Paris. https://doi.org/10.1787/9789264043466-en

[38] Oriangi, G., Albrecht, F., Bamutaze, Y., Mukwaya, P.I. and Nakileza, B. (Unpublished) Community Perceptions of Resilience to Climate Induced Hazards in Mbale Municipality, Uganda.

[39] Ilmola, L. (2016) Approaches to Measurement of Urban Resilience. Springer, Berlin, 207-237. https://doi.org/10.1007/978-3-319-39812-9

[40] Meerow, S., Newell, J.P. and Stults, M. (2016) Defining Urban Resilience: A Review. Landscape and Urban Planning, 147, 38-49. https://doi.org/10.1016/j.landurbplan.2015.11.011

[41] Aldunce, P., Beilin, R., Handmer, J. and Howden, M. (2016) Stakeholder Participation in Building Resilience to Disasters in a Changing Climate. Environmental Hazards, 15, 58-73. https://doi.org/10.1080/17477891.2015.1134427

[42] UBOS (2016) 2014 Uganda Population and Housing Census Analytical Report, Kampala.

[43] Mbale District Local Government (2012) Mbale District Local Government Statistical Abstract, Kampala.

[44] UNDP (2013) Climate Profile and Climate Change Vulnerability Assessment for the Mbale Region of Uganda, Kampala.

[45] Bennett, S. and Iiyanagec, W.M. (1998) Simplified General Method for Cluster Sample Surveys. World Health, 44, 98-106.

[46] Yamane, T. (1967) Statistics: An Introductory Analysis. Harper and Row, 60, 886. https://doi.org/10.2307/2282703

[47] Freudenberg, M. (2003) Composite Indicators of Country Performance: A Critical Assessment. OECD Science Technology and Industry Working Papers No. 16, OECD Publishing, Paris. https://doi.org/10.1787/405566708255

[48] Mayunga, J.S. (2007) Understanding and Applying the Concept of Community Disaster Resilience: A Capital-Based Approach, USA. https://doi.org/10.1146/annurev.energy.32.051807.090348

[49] Kansiime, M.K., Wambugu, S.K. and Shisanya, C.A. (2013) Perceived and Actual Rainfall Trends and Variability in Eastern Uganda. Journal of Natural Sciences Research, 3, 179-195.

[50] Oriangi, G., Albrecht, F., Di Baldassarre, G., Bamutaze, Y., Mukwaya, P.I., Ardö, J. and Pilejö, P. (in press) Household Resilience to Climate Change Hazards in Uganda. International Journal of Climate Change Strategies and Management.

[51] FAO-UNICEF-WFP (2014) Household Resilience in Dolow, Somalia.

[52] Mehedi, B.L., Mohammed, H., Asaduzzaman, S., Mohammed, Nasir, U. and Zulfikar, R. (2018) Role of a Coastal NGO in Attaining Climate Resilience in Bangladesh. American Journal of Climate Change, 7, 17-39.

[53] Aldrich, P.D. and Meyer, M. (2014) Social Capital and Community Resilience. 
American Behavioral Scientist, 59, 254-269.

https://doi.org/10.1177/0002764214550299

[54] Tawodzera, G. (2012) Urban Household Survival and Resilience to Food Insecurity in Crisis Conditions: The Case of Epworth in Harare, Zimbabwe. Journal of Hunger \& Environmental Nutrition, 7, 293-320.

https://doi.org/10.1080/19320248.2012.702469

[55] Tippens, J.A. (2016) Urban Congolese Refugees in Kenya: The Contingencies of Coping and Resilience in a Context Marked by Structural Vulnerability in Nairobi. Faculty Publication, Department of Child, Youth and Family Studies, University of Nebraska-Lincoln. https://doi.org/10.1177/1049732316665348 